\title{
Removal of Heavy Metals in Water with Adsorbents Derived from Pig Manure
}

\author{
Jens Maggen ${ }^{1}$, Robert Carleer ${ }^{1}$, Jan Yperman ${ }^{1}$, Sonja Schreurs ${ }^{2}$ \\ ${ }^{1}$ Applied and Analytical Chemistry, Hasselt University \\ Agoralaan Gebouw D, B-3590, Diepenbeek, Belgium \\ jens.maggen@uhasselt.be; robert.carleer@uhasselt.be; jan.yperman@uhasselt.be \\ ${ }^{2} \mathrm{NuTeC}$, Hasselt University \\ Agoralaan Gebouw H, B-3590, Diepenbeek, Belgium \\ sonja.schreurs@uhasselt.be
}

\section{Extended Abstract}

Heavy metals in natural waters such as lead, cadmium and nickel are considered to be toxic from a certain concentration and especially in a particular chemical form (speciation). The maximum allowable concentrations of these heavy metals in water are $0.01 \mathrm{mg} / \mathrm{L}$ for $\mathrm{Pb}, 0.003 \mathrm{mg} / \mathrm{L}$ for $\mathrm{Cd}$ and $0.02 \mathrm{mg} / \mathrm{L}$ for $\mathrm{Ni}$ (WHO). Heavy metals are removed from the environment through sand filters, ion exchangers, coagulation and activated carbon (AC).

AC's are very efficient as an adsorbent because of their high porosity, high specific surface area, and high degree of surface reactivity [1] but are suffering from high production costs (three kilos of high quality coal is needed per kg AC produced). The challenge is a conversion-route / method with a lower cost, techno-economically attractive and producing AC's with similar or superior characteristics then the commercial available AC's starting from suitable biomass rest streams like pig manure. Simultaneously, a reduction of waste disposal and protection of the environment will be achieved [2], [3]. There are three key steps in the production of AC from pig manure. First, dewatering of the pig manure is needed and is done by a reverse osmotic process. Next, a carbonization of the $30 \%$ wet material is performed at $450^{\circ} \mathrm{C}$ in the absence of oxygen. This material, biochar, can already be used as an alternative adsorbent for commercial AC's. And finally in the last step, the biochar is activated with steam at temperatures above $800^{\circ} \mathrm{C} \mathrm{[4]} \mathrm{resulting} \mathrm{in} \mathrm{AC}$.

The biochar and the corresponding $\mathrm{AC}$ are investigated for adsorption of $\mathrm{Pb}, \mathrm{Cd}$ and $\mathrm{Ni}$ compared with commercial ACs. This is performed by a simple but reliable two point method developed within our research group at Hasselt University. This method uses two different masses of adsorption material at two different $\mathrm{pH}$ 's, but keeping the concentration of the heavy metal constant. The results reveal that pig manure based biochar adsorbs around $83 \%$ of $\mathrm{Pb}$, $60 \%$ of $\mathrm{Cd}$ and $80 \%$ of Ni. Further activation to $\mathrm{AC}$ improves the adsorption to a level almost $100 \%$ of the $\mathrm{Pb}, \mathrm{Cd}$ and $\mathrm{Ni}$ present at concentrations of $10 \mathrm{ppm}$ each. The commercial AC's adsorbs only $5 \%$ of $\mathrm{Pb}$ and $48 \%$ of $\mathrm{Cd}$ at the same concentration levels. The percentage of adsorption for $\mathrm{Ni}$ is the same as for the biochar. Langmuir and Freundlich adsorption isotherms are explored to determine the adsorption behaviour. Adsorption kinetics are examined by first, second and $\mathrm{n}$-th (mixed) order kinetics for a better understanding of the adsorption mechanism.

\section{References}

[1] J. M. Dias, M. C. M. Alvim-Ferraz, M. F. Almeida, J. Rivera-Utrilla, M. Sanchez-Polo, "Waste materials for activated carbon preparation and its use in aqueous-phase treatment: A review," (in English), Journal of Environmental Management, vol. 85, no. 4, pp. 833-846, 2007.

[2] R. Azargohar, A. K. Dalai, "Biochar as a precursor of activated carbon," Applied Biochemistry and Biotechnology, vol. 131, no. 1-3, pp. 762-773, 2006.

[3] K. S. Ro, K. B. Cantrell, P. G. Hunt, "High-Temperature Pyrolysis of Blended Animal Manures for Producing Renewable Energy and Value-Added Biochar," Industrial \& Engineering Chemistry Research, vol. 49, no. 20, pp. 10125-10131, 2010. 
[4] T. Tay, S. Ucar, S. Karagoz, "Preparation and characterization of activated carbon from waste biomass," Journal of Hazardous Materials, Article vol. 165, no. 1-3, pp. 481-485, 2009. 